\title{
Black Carbon and Particulate Organic Toxics Emitted by Sugarcane Burning in Veracruz, México
}

\author{
Violeta Mugica-Álvarez, Sandra Ramos-Guízar, Naxieli Santiago-de la Rosa, Miguel Torres-Rodríguez, \\ and Luis Noreña-Franco
}

\begin{abstract}
Sugar cane industry signifies a very important income for the Mexican economy; nevertheless, the inadequate agricultural practices, promote the emission of tons of atmospheric particles (PM). In order to have a better understanding about the toxics contained in the particle emission from sugarcane burning, two sampling campaigns to collect fine particles $\left(\mathbf{P M}_{2.5}\right)$ and respirable particles $\left(\mathbf{P M}_{10}\right)$ during and after the harvest season, were performed in the municipality of Córdoba, Veracruz, México, a small city next to many sugarcane crops. Results showed that particles concentrations increased around $41 \%$ for $\mathrm{PM}_{10}$ and $32 \%$ for $\mathbf{P M}_{2.5}$, whereas black carbon concentrations increased $25 \%$ and $28 \%$ respectively. The high $\mathrm{PM}_{2.5} / \mathrm{PM}_{10}$ ratio of 0.7 during harvest shows that most of the particles and toxic are contained in the fine fraction, in addition, the sum of carcinogenic polycyclic aromatic hydrocarbons(PAHs) was around $50 \%$ of total PAHs, with a BAPeq of $996 \mathrm{pg} \mathrm{m}^{-3}$ during harvesting; these results represents an important risk for the neighboring population, consequently authorities and decision makers should attend and implement control strategies.
\end{abstract} PAHs.

Index Terms-Sugarcane burning, $\mathbf{P M}_{2.5}$, black carbon,

\section{INTRODUCTION}

During 2013, 780,000 ha of crops were harvested in México, producing 61 millions of tons of sugarcane yielding 78.7 ton $\mathrm{ha}^{-1}$ [1]. The sugarcane growing is carried out in 15 states, where Veracruz contributes to $36 \%$ of National production [2]. The harvest season of sugarcane lasts between 5 to six months, and during this time, tons of pollutants are emitted to the atmosphere due to burning of biomass which facilitate the work of farmers reducing weeds and moving away insects and snakes; in addition after harvesting, wastes are burned in order to prepare the land for the next planting [3].

Among the most important emitted pollutants during sugarcane burning, particles are of concern since, on one hand they include toxic compounds such as polycyclic aromatic hydrocarbons (PAHs), which are semi-volatile species formed by the fusion of two or more benzene rings through a pyrolytic process during incomplete combustion of organic materials [4]. PAHs have a significant importance in the mutagenic activity of atmospheric particles and some of them

Manuscript received March 20, 2015; revised June 16, 2015. This work was supported by the CONACYT under Project 181231 and by the Universidad Autónoma Metropolitana-Azcapotzalco.

The authors are with the Universidad Autónoma Metropolitana-Azcapotzalco, México (e-mail: vma@correo.azc.uam.mx, trm@correo.azc.uam.mx,.lnf@correo.azc.uam.mx). have been classified as carcinogenic, such as benzo[a]pyrene, benzo[a]anthracene, chrysene, dibenzo[a, $\mathrm{h}]$ anthracenebenzo[b]fluorantene, benzo[k]fluorantene, and indene[1,2,3-cd]pyrene [5]. On the other hand, the emitted particles contain black carbon which is a known short-lived climate forcer which contributes to global warming; further black carbon has been associated to 2 million of premature deaths, due to inhalation from domestic cooking [6].

Studies in Brazil reported high correlation between sugarcane burning season and the intensification of admission of children to the hospital because of respiratory illness [7], [8]. Information about the environmental sugarcane burning is scarce and is related mainly to researches in Brazil and Colombia [9]-[11]. In México, only was found one study related to this issue, which concluded that people living next to sugarcane crops have more frequent respiratory illness who those in other sites of the State of Puebla [12].

In this paper, two sampling campaigns were carried out close to the sugarcane to compare the concentrations of $\mathrm{PM}_{10}$ and $\mathrm{PM}_{2.5}$ during harvest and no-harvest season; in addition the quantification of the levels of black carbon and polycyclic aromatic hydrocarbons contained in particles was performed to determine the occurrence of toxic species.

\section{METHODOLOGY}

\section{A. Sampling}

Sampling site is located in the municipality of Córdoba, Veracruz $\left(18^{\circ} 53^{\prime} \mathrm{N}\right.$; $\left.96^{\circ} 56^{\prime} \mathrm{W}\right)$ which is located at $860 \mathrm{~m}$ above sea level, in the most important sugarcane zone in Veracruz State which comprises 9 sugar mills and around 200,000 inhabitants.

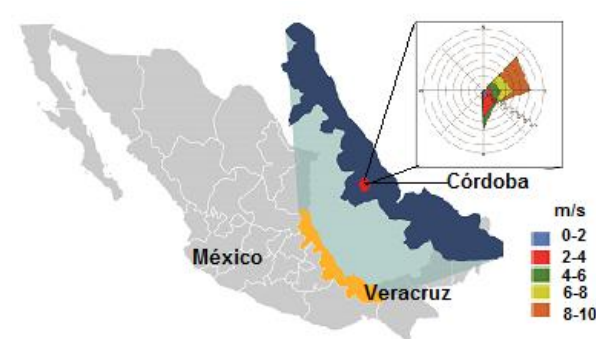

Fig. 1. Study site: Córdoba in the State of Veracruz in México.

The weather is warm-humid with an average temperature of $19.9^{\circ} \mathrm{C}$, ranging from $6^{\circ} \mathrm{C}$ to $35^{\circ}$. Fig. 1 shows the location as well as the wind rose during harvest season.

Collection of fine particles $\left(\mathrm{PM}_{2.5}\right)$ and respirable particles $\left(\mathrm{PM}_{10}\right)$ were performed using $20 \times 25 \mathrm{cmWhatman}$ quartz fiber filters, previously calcined at $550{ }^{\circ} \mathrm{C}$ to remove organic 
matter. Filters were placed in Hi Vol equipment's (Tish Environment) and $24 \mathrm{~h}$ integrated samples were collected during 30 days. The samplings in the harvest and no-harvest seasons were in April and July 2013, respectively. After collection, filters were wrapped with foil and stored at $-4{ }^{\circ} \mathrm{C}$. Meteorology data were collected in the site with the meteorological station of the Universidad Veracruzana.

\section{B. Analysis}

After gravimetric analysis, PAHs were extracted by immersing a piece of filter in an ultrasonic bath (Bransonic) with dichloromethane, thrice for $10 \mathrm{~min}$ periods at $10^{\circ} \mathrm{C}$. The extracts were concentrated in a rotary evaporator, filter with syringe filters, brought to $1 \mathrm{~mL}$ and stored in amber glass vials at $-18^{\circ} \mathrm{C}$ until chromatographic analysis [13]. A gas chromatograph mass spectrometer (GC model HP 6890)with a quadrupole mass filter and an autosampler (model 5973) was used with a $30 \mathrm{~m}$ HP5-MS capillary column $(0.25 \mathrm{~mm}$ id, $0.25 \mu \mathrm{m}$ film thickness)for identification and quantification of PAHs. The oven temperature was operatedat $65^{\circ} \mathrm{C}$ for $2 \mathrm{~min}$, and increased $8{ }^{\circ} \mathrm{C} / \mathrm{min}$ to $320^{\circ} \mathrm{C}$, held for $10 \mathrm{~min}$. Highpurity helium was used as the carrier gas at a flow rate of $1 \mathrm{~mL}$ min.Fluoranthene d10 was added as internal standard according to Method TO-13A [13]. A standard PAH mixture was used for quantification of: naphthalene (NAP), methylnaphtalene (MNAP), acenaphthylene (ACY), acenaphtene (ACE), anthracene (ANT), phenanthrene (PHE), benzo[a]pyrene (BAP), benzo[b]fluoranthene (BBF), benzo[a]anthracene (BAA), fluorene (FLU), fluoranthene (FLT), pyrene (PYR), chrysene (CRY), benzo[k]fluoranthene (BKF), 2 methylnaphtalene (MNAP), dibenzo[a,h]anthracene (DBA),indene[1,2,3-cd]pyrene (IND), and benzo[ghi]perylene (BGP). Further, toxic equivalent factors (TEFs) were applied to estimate the carcinogenic potency of the PAHs mixture.

A Thermal-Optical Carbon Aerosol Analyzer with reflectance correction (Sunset Lab, ForestGrove, OR USA), was used to determine organic and elementalcarbon (OC and EC), which were determined by automatedthermal-optical transmittance (TOT), using the National Institutefor Occupational Safety and Health method (NIOSH) 5040described by Birch and Cary [14].

\section{Statistical Analysis}

Medians of pollutants in the two sizesand seasons were compared to establish significant differences in theconcentrations measured using the non-parametric Mann-Whitney test.The statistical analyses were carriedout with SPSS 22.0 for Windows 2013.

\section{RESULTS AND DISCUSSION}

Table I displays the basic statistics of particle concentrations, as well as carbonaceous species and total PAHs. Concentrations of $\mathrm{PM}_{10}$ and $\mathrm{PM}_{2.5}$ increased $41 \%$ and $32 \%$ respectively during harvest concentrations, despite that during harvest season the occurrence of strong winds $>8 \mathrm{~m} \mathrm{~s}^{-1}$ was frequent favoring the pollutant dispersion. The Mann-Withney test presented significant differences between $\mathrm{PM}_{10}$ and $\mathrm{PM}_{2.5}$ concentrations during the two periods ( $p<$
0.01), showing statistical increase in the concentration levels of both size of particles. Only two days the $24 \mathrm{~h} \mathrm{PM}_{10}$ and $\mathrm{PM}_{2.5}$ Mexican standards (120 $\mu \mathrm{g} \mathrm{m}^{-3}$ and $65 \mu \mathrm{g} \mathrm{m} \mathrm{m}^{-3}$, respectively) were exceeded during harvesting time; in opposite, through no-harvest the concentrations of both sizes of particles were never exceeded. The $\mathrm{PM}_{2.5} / \mathrm{PM}_{10}$ ratio shows that during harvest $70 \%$ of the particles are in the fine fraction which is of concern since these particles can penetrate deeper in the respiratory system. These results are similar to those reported in Araraquara, in Brazil where during harvest the concentration levels ranged from 41 to $182 \mu \mathrm{g} \mathrm{m}^{-3}$, while during no-harvest concentrations were 12 to $41 \mathrm{\mu g} \mathrm{m}^{-3}$ [9].

The quantification of black carbon (BC) has gained attention in the last years since the World Health Organization reported that cohort studies have provided enough evidence of associations of all-cause and cardiopulmonary mortality with long-term average $\mathrm{BC}$ exposure [15]. The terms black carbon and elemental carbon are often used interchangeable, but there is a difference related to the analytical method used. Black carbon refers to the dark, light-absorbing components of aerosols, whereas elemental carbon is measured with ananalytic thermal method [16], nevertheless, in the reports of the Intergovernmental Panel of Climate Change (IPCC) only the term black carbon is used regardless the measurement method [17]. It has been stated that black carbon is the second cause of global warming since the radiative forcing of $\mathrm{BC}$ in a period of 20 years is 2200 times higher than the global warming power of $\mathrm{CO}_{2}$ [18].

TABLE I: Descriptive Statistic of Measured Pollutant CONCENTRATIONS

\begin{tabular}{|c|c|c|c|c|c|c|}
\hline & \multicolumn{3}{|c|}{ HARVEST } & \multicolumn{3}{|c|}{ NO HARVEST } \\
\hline & MEAN & MAX & MIN & MEAN & MAX & MIN \\
\hline$\mu \mathrm{g} \mathrm{m}^{-3}$ & & & & & & \\
\hline $\mathbf{P M}_{10}$ & $91 \pm 19.1$ & 134.2 & 56.5 & $53.9 \pm 15.2$ & 81.5 & 15.0 \\
\hline $\mathrm{OC}_{10}$ & $16 \pm 8.1$ & 33.6 & 7.7 & $7.7 \pm 2.2$ & 11.6 & 2.2 \\
\hline $\mathrm{BC}_{10}$ & $4.9 \pm 1.0$ & 6.7 & 1 & $3.7 \pm 1.0$ & 6.3 & 2.7 \\
\hline $\mathrm{TC}_{10}$ & $19.8 \pm 9.7$ & 40.2 & 8.5 & $10.91 \pm 3.1$ & 16.5 & 3.1 \\
\hline 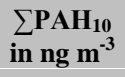 & $6.17 \pm 0.99$ & 9.23 & 4.38 & $\begin{array}{c}3.46 \pm 0.86 \\
7\end{array}$ & 4.89 & 2.13 \\
\hline$\mu \mathrm{g} \mathrm{m}^{-3}$ & MEAN & MAX & MIN & MEAN & MAX & MIN \\
\hline $\mathbf{P M}_{2.5}$ & $51.3 \pm 27$ & 108.2 & 41.9 & $34.9 \pm 3.9$ & 43.9 & 30.1 \\
\hline $\mathrm{OC}_{2.5}$ & $13.8 \pm 2.9$ & 18.1 & 3.8 & $5.1 \pm 0.6$ & 6.3 & 4.2 \\
\hline $\mathrm{BC}_{2.5}$ & $3.2 \pm 0.6$ & 6.3 & 1 & $2.3 \pm 0.4$ & 2.9 & 1.6 \\
\hline $\mathrm{TC}_{2.5}$ & $16.2 \pm 3.9$ & 22.5 & 10.4 & $7.35 \pm 1$ & 9.3 & 5.8 \\
\hline 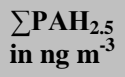 & $5.03 \pm 0.71$ & 6.97 & 3.86 & $\begin{array}{c}2.72 \pm 0.61 \\
3\end{array}$ & 4.11 & 1.94 \\
\hline $\begin{array}{l}\mathbf{P M}_{2.5} / \\
\mathbf{P M}_{10}\end{array}$ & $0.7 \pm 0.1$ & 0.86 & 0.34 & $0.6 \pm 0.1$ & 0.81 & 0.4 \\
\hline $\begin{array}{l}\mathrm{OC}_{2.5} / \\
\mathrm{OC}_{10}\end{array}$ & $0.9 \pm 0.1$ & 0.93 & 0.09 & $0.7 \pm 0.1$ & 0.75 & 0.6 \\
\hline $\begin{array}{c}\mathrm{BC}_{2.5} / \\
\mathrm{BC}_{10}\end{array}$ & $07 \pm 0.1$ & 0.81 & 0.08 & $0.6 \pm 0.1$ & 0.76 & 0.6 \\
\hline $\begin{array}{l}\mathrm{TC}_{2.5} / \\
\mathrm{TC}_{10}\end{array}$ & $0.9 \pm 0.1$ & 0.93 & 0.07 & $0.7 \pm 0.1$ & 0.76 & 0.6 \\
\hline $\begin{array}{l}\sum \mathbf{P A H}_{10} / \\
\sum \mathbf{P A H}_{2.5}\end{array}$ & 0.82 & 0.90 & 0.75 & 0.79 & 0.84 & 0.76 \\
\hline
\end{tabular}

Total carbon was 1.8 and 1.5 times higher during the harvest period for $\mathrm{PM}_{10}$ and $\mathrm{PM}_{2.5}$ respectively; organic carbon concentration levels were 2.1 times greater for $\mathrm{PM}_{10}$ 
and 2.7 times for $\mathrm{PM}_{2.5}$ during harvest, whereas black carbon increased 1.3 and 1.4 times respectively contributing with the $5 \%$ of the total mass of $\mathrm{PM}_{10}$ and $7 \%$ of the total mass of $\mathrm{PM}_{2.5}$.

The BC level concentrations measured in this study are in agreement with the reported concentrations in Southeastern Brazil [19]. Concentrations of total carbon, organic carbon and black carbon during harvest and no harvest were statistically different for both sizes of particles.

The measured increases observed in black carbon suggest that sugarcane burning is not only a health concern but also a climate worry for the positive radiative forcing that increases global warming. Regarding the total PAH concentrations, the levels were 1.8 and 1.9 times greater for $\mathrm{PM}_{10}$ and $\mathrm{PM}_{2.5}$ respectively, during harvest than no-harvest period, exhibiting statistical differences $(p<0.05)$.

The high ratio of $\mathrm{PM}_{2.5} / \mathrm{PM}_{10}(0.7)$ means that $70 \%$ of particles are in the fine fraction, whereas $90 \%$ and $82 \%$ of OC and PAHs are in that fraction that can penetrate deeper in the lungs. Despite the $\mathrm{PM}_{10}$ concentrations measured in this study are quite similar to those measured in Araraquara, Brazil, the total PAHs concentrations in Veracruz were lower than the $11.6 \mathrm{ng} \mathrm{m}^{-3}$ reported in Brazil during harvest and $3.5 \mathrm{ng} \mathrm{m}^{-3}$ during no-harvest [9]; other study in the same city in Brazil [20] reported also high average concentrations of total PAHs with $25.9 \mathrm{ng} \mathrm{m}^{-3}$ during harvest. The most abundant PAHs were IND, BBF, BAP, BGP PYR and FLT, whereas ANT, FLU and ACE showed the lowest concentrations (Fig. 2).

During harvest, the sum of carcinogenic PAHs (BAP, BAA, $\mathrm{BBF}, \mathrm{BKF}, \mathrm{CRY}, \mathrm{DBA}$ and IND) was $3.1 \mathrm{ng} \mathrm{m}^{-3}$ for $\mathrm{PM}_{10}$ and $2.5 \mathrm{ng} \mathrm{m}^{-3}$ for $\mathrm{PM}_{2.5}$, which is equivalent to $50 \%$ of total PAHs These values are 1.8 and 1.9 higher than the sum of carcinogenic PAHs during no-harvest, $1.7 \mathrm{ng} \mathrm{m}^{-3}$ and $1.3 \mathrm{ng}$ $\mathrm{m}^{-3}$ for $\mathrm{PM}_{10}$ and $\mathrm{PM}_{2.5}$ respectively. These results suggest that the risk of cancer increases during harvesting, since half of PAHs concentrations are associated to the seven carcinogenic PAHs. In addition, the emitted PAHs could have secondary reactions in the atmosphere and produce nitro PAHs, chlorinated PAHs and oxy PAHs, which in general have a greater mutagenic activity in comparison with their precursors, maybe due to a greater polarity [21].

For more than 25 years BAP has been considered the reference PAH for whole PAH carcinogenicity.The European Union proposed $1 \mathrm{ng} \mathrm{m}^{-3}$ as an annual average for BAP in $\mathrm{PM}_{10}$ [22], whereas $0.25 \mathrm{ng} \mathrm{m}^{-3}$ is the annual average air quality standard in the United Kingdom [23]. The mean obtained for BAP during harvest was 0.49 which exceeds the United Kingdom standard but not that of European Union, in opposite, in no-harvest the mean concentration of BAP was $0.24 \mathrm{ng} \mathrm{m}^{-3}$.

Table II shows the comparison of BAP concentrations measured in this study with those reported in other studies developed in rural areas where sugarcane is grown, as well as with the levels found in some cities.In general, BAP concentrations in $\mathrm{PM}_{10}$ of this study are in agreement with similar researches in sugarcane zones, and the concentrations of this PAH is lower than in big cities such as Porto Allegre, Hong Kong and Mexico City.

Some of the other PAH could have a medium or high carcinogenic potency, which suggested that the merely determination of BAP could be insufficient; hence, toxic equivalent factors (TEF) were developed with the aim of estimating the carcinogenic potential of different PAHs in terms of BAPeq carcinogenicity, multiplying the concentrations of each PAH by the corresponding TEF [22].

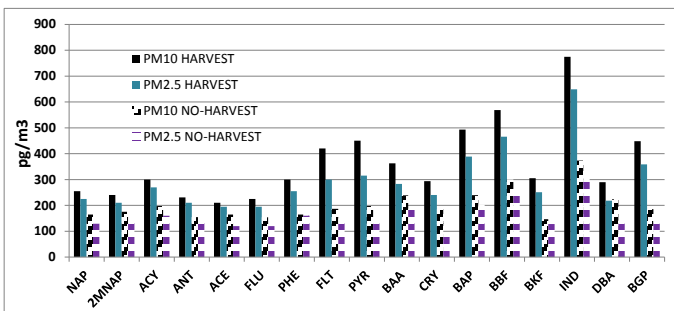

Fig. 2. Concentrations of individual PAH in two sizes of particles and both seasons.

\begin{tabular}{|c|c|c|c|c|}
\hline Site & Ref. & Year & $\begin{array}{l}\text { BAP } \\
\mathrm{PM}_{10}\end{array}$ & $\sum \mathrm{PAH}$ \\
\hline $\begin{array}{l}\text { Araraquara, } \\
\text { Brazil } \\
\text { sugarcane }\end{array}$ & [9] & 2010 & 0.46 & 11.6 \\
\hline $\begin{array}{l}\text { Araraquara, Brasil } \\
\text { Sugarcane rural }\end{array}$ & [20] & 2014 & 0.42 & 25.9 \\
\hline $\begin{array}{l}\text { Zaragoza, España } \\
\text { City, Cold season }\end{array}$ & [25] & 2013 & 0.15 & 2.84 \\
\hline $\begin{array}{l}\text { Hong Kong, China } \\
\text { City }\end{array}$ & [26] & 2003 & 2.13 & \\
\hline $\begin{array}{l}\text { Venice, Italia, city } \\
\text { annual }\end{array}$ & [27] & 2012 & 1.2 & 9.8 \\
\hline $\begin{array}{l}\text { Cauco, Colombia } \\
\text { Sugarcane rural }\end{array}$ & [11] & 2013 & 0.54 & 2.45 \\
\hline $\begin{array}{l}\text { Porto Allegre, } \\
\text { Brazil, City }\end{array}$ & [28] & 2005 & 1.09 & \\
\hline México City & [29] & 2010 & 0.81 & 10.5 \\
\hline Harvest & \multicolumn{2}{|c|}{ This study } & 0.49 & 6.2 \\
\hline No-harvest & \multicolumn{2}{|c|}{ This study } & 0.24 & 3.5 \\
\hline
\end{tabular}

TABLE III: BAP $\mathrm{BQ}_{\mathrm{O}}$ OF PAHS IN $\mathrm{PM}_{10}$

\begin{tabular}{lccccc} 
& \multicolumn{4}{c}{ HARVEST } & NO-HARVEST \\
\hline PAH & TEF & $\mathrm{pg} \mathrm{m}^{3}$ & $\mathrm{pg} \mathrm{m}^{3}$ & $\mathrm{pg} \mathrm{m}^{3}$ & $\mathrm{pg} \mathrm{m}^{3}$ \\
& & PM $_{\mathbf{1 0}}$ & $\mathbf{P M}_{\mathbf{2 . 5}}$ & PM $_{\mathbf{1 0}}$ & PM $_{\mathbf{2 . 5}}$ \\
IND & 0.1 & 77.49 & 64.92 & 37.378 & 31.12 \\
BBF & 0.1 & 56.865 & 46.545 & 30.096 & 23.77 \\
BAP & 1 & 493.25 & 389 & 240.15 & 203.67 \\
BGP & 0.01 & 4.485 & 3.585 & 1.859 & 1.44 \\
PYR & 0.001 & 0.45 & 0.315 & 0.198 & 0.15 \\
FLT & 0.001 & 0.42 & 0.3 & 0.187 & 0.15 \\
BAA & 0.1 & 36.27 & 28.32 & 23.925 & 18.74 \\
ACY & 0.001 & 0.3 & 0.27 & 0.198 & 0.16 \\
PHE & 0.001 & 0.3 & 0.255 & 0.165 & 0.16 \\
BKF & 0.1 & 30.48 & 25.11 & 14.707 & 12.81 \\
CRY & 0.01 & 2.94 & 2.4 & 1.859 & 0.97 \\
DAA & 1 & 289.71 & 218.24 & 224.09 & 142.57 \\
NAP & 0.001 & 0.255 & 0.225 & 0.165 & 0.13 \\
\hline 2MNAP & 0.001 & 0.24 & 0.21 & 0.176 & 0.14 \\
\hline ANT & 0.01 & 2.31 & 2.1 & 1.551 & 1.38 \\
FLU & 0.001 & 0.225 & 0.195 & 0.154 & 0.12 \\
\hline ACE & 0.001 & 0.21 & 0.195 & 0.165 & 0.12 \\
BAPeq & & $\mathbf{9 9 6 . 2 0}$ & $\mathbf{7 8 2 . 1 8}$ & $\mathbf{5 7 7 . 0 3}$ & $\mathbf{4 3 7 . 6 0}$ \\
\hline
\end{tabular}

TEF: Toxic equivalent factors.

Table III presents the TEFs for each average value of PAHs developed by Nisbet and La Goy [24], as well as the estimation of BAPeq in the mixture. It is possible observe that the maximum value was obtained during harvest $\mathrm{PM}_{10}$; although the BAPeq is equal to the standard proposed by the European Union of $1 \mathrm{ng} \mathrm{m}^{3}$, it is relevant to mention that the population is exposed for six months straight, and the 
mentioned standard was designed for an annual exposure with variations in the PAH concentrations among the days.

\section{CONCLUSIONS}

The exposure to $\mathrm{PM}_{10}$ and $\mathrm{PM}_{2.5}$ of the neighboring population to sugarcane crops was respectively 1.7 and 1.5 times higher during the harvest period than in the no harvest, increasing the health risk. These particles contain toxic species such as black carbon and polycyclic aromatic hydrocarbons.

According with the $\mathrm{PM}_{25} / \mathrm{PM}_{10}$ ratios, $70 \%$ of particles and $\mathrm{BC}$ are in the $\mathrm{PM}_{2.5}$ fraction, whereas in the case of PAHs $82 \%$ are in the fine fraction, which increases the risk to respiratory illness, due that fine particles can penetrate deeper in the lungs.

The increase of black carbon and carcinogenic organic compounds, such as PAHs must be considered in the risk assessment conducted by health authorities, not only $\mathrm{PM}_{10}$ and $\mathrm{PM}_{2.5}$.

Level concentrations of black carbon during harvest were $25 \%$ and $28 \%$ greater for $\mathrm{PM}_{10}$ and $\mathrm{PM}_{2.5}$, which in addition to the health risk for population, have implications in global warming; therefore, integrated policies which address climate change and air pollution health effects are required for an effective control of these emissions.

\section{ACKNOWLEDGMENT}

The authors thank CONACYT for the support to the Project 181231 and for the graduate student scholarship given to Sandra Ramos and Naxieli Santiago.

\section{REFERENCES}

[1] Conadesuca. (2013). Closing reports. System INFOR Caña. [Online]. Available:

http://www.campomexicano.gob.mx/azcf/reportes/reportes.php?tipo= CIERRE.

[2] Sagarpa. Ministry of agriculture, livestock, rural development, fishing, and feeding. Sugarcane. [Online]. Available: http://w4.siap.gob.mx/sispro/Integra/Caracteristicas/CanaAzu.html

[3] T. G. S. Neto, J. A. Carvalho, E. V. Cortez et al., "Laboratory evaluation of Amazon forest biomass burning emissions," Atmos. Environ., vol. 45, pp. 7455-7461, 2011.

[4] V. Mugica, M. Torres, E. Salinas, M. Gutierrez, and R. García, "Polycyclicaromatichydrocarbons in theurbanatmosphere of Mexicocity," Air Pollution, Debeljuh, Scyio., 2010, pp. 75-97.

[5] IARC, "International agency for research on cancer," Air Pollution and Cancer, IARC Scientific Publications, vol. 161, 2013.

[6] UNEP and WMO, "Integrated assessment of black carbon and tropospheric ozone summary for decision makers," 2011.

[7] J. E. D. Cançado, P. H. N. Saldiva, L. A. A. Pereira et al., "The impact of sugarcane burning emissions on the respiratory system of children and elderly," Environ. Health Perspect., vol. 114, pp. 725-729, 2006.

[8] M. Uriarte, C. B. Yackulic, T. Cooper et al., "Expansion of sugarcane production in São Paulo, Brazil: Implications for fire occurrence and respiratory health," Agric. Ecosys. Environ., vol. 132, no. 1, pp. 48-56, 2009.

[9] S. J. Andrade, J. Cristale, F. S. Silva, G. J. Zocolo, and M. R. Marchi, "Contribution of sugar-cane harvesting season to atmospheric contamination by polycyclic aromatic hydrocarbons (PAHs) in Araraquara city, Southeast Brazil," Atmos. Environ., vol. 44, no. 24, pp 2913-2919, 2010.

[10] J. Cristale, F. S. Silva, G. J. Zocolo, and M. R. R. Marchi, "Influence of sugarcane burning on indoor/outdoor PAH air pollution in Brazil," Environ. Pollut., vol. 169, pp. 210-216, 2012.

[11] D. M. R. Cárdenas, H. S. Vela, and J. E. P. Quinche, "Estimation of polycyclic aromatic hydrocarbons and heavy metals associated with sugarcane burning in the cauca geographyc valley Colombia," Epsilon, vol. 21 , pp. 57-82, 2014.

[12] A. Navarro et al., "Atmospheric particles and its relationship with biomass burning," in Proc. VI Congreso Internacional de Quimica e Ingenieria Quimica, Habana, Cuba, 2006.

[13] US. Environment Protection Agency, "Compendium method TO-13," Determination of Polycyclic Aromatic Hydrocarbons in Ambient Air Using Gas Chromatographic Mass Spectrometry (GC-MS).

[14] M. E. Birch and R. A. Cary, "Elemental carbon-based method for monitoring occupational exposures to particulate diesel exhaust," Aerosol Science and Technology, vol. 25, no. 3, pp. 221-241, 1996.

[15] N. Janssen, M. Gerlofs-Nijland, T. Lanki et al., Health Effects of Black Carbon, World Health Organization, Copenhagen, 2012, p. 96.

[16] Y. M. Han, "Evaluation of the thermal/optical reflectance method for discrimination between char- and soot-EC," Chemosphere, vol. 69, pp 569-574, 2007.

[17] J. Feng, Y. Chen, H. Guo, G. Zhi, S. Xiong, J. Li, and J. Fu, "Characteristics of organic and elemental carbon in $\mathrm{PM}_{2.5}$ samples in Shanghai, China," Atmospheric Research, vol. 92, pp. 434-442, 2009.

[18] R. E. Baron, W. D. Montgomery, and S. D. Tuladhar, "An analysis of black carbon mitigation as a response to climate change," CRA International Washington DC for Copenhagen Consensus Center,2009

[19] L. L. Lara, P. Artaxo, L. A. Martinelli, P. B. Camargo, R. L. Victoria, and E. S. B. Ferraz, "Properties of aerosols from sugar-cane burning emissions in Southeastern Brazil," Atmospheric Environment, vol. 39, pp. 4627-4637, 2005.

[20] J. Assuncao, C. Pesquero, A. Nardocci, A. Francisco, N. Soares, and H Ribeiro, "Airborne polycyclic aromatic hydrocarbons in a medium-sized city affected by pre-harvestsugarcane burning and inhalation risk for human health," Journal of the Air \& Waste Management Association, 2014.

[21] T. Ohura, "Environmental behavior, sources, and effects of chlorinated polycyclic aromatic hydrocarbons," The Scientific World Journal, pp. 372-380, 2007.

[22] European Directive, Directive 2004/107/EC of the European Parliamentand of the Council of 15 December 2004 relating to arsenic, cadmium, mercury, nickel and polycyclic aromatic hydrocarbons inambient air, Official Journal of the European Union L23, pp. 3-16, 2004.

[23] Expert Panel on Air Quality Standards. (1999). A recommendation for a United Kingdom air quality standard for polycyclic aromatic hydrocarbons. Department of the Environment. [Online]. Available: http://www.scotland.gov.uk/News/Releases/1999/07/f42c49e8-a7b342bc-8e60-fb717eda9584

[24] D. Nisbet and P. L. Goy, "Toxic equivalence factors (TEFs) for polycyclic aromatic hydrocarbons (PAHs)," Regul. Toxicol Pharmacol., vol. 16, pp. 290-300, 1992.

[25] M. S. Callén, J. M. López, A. Iturmendi, and A. M. Mastral, "Nature and sources of particle associated polycyclic aromatic hydrocarbons $(\mathrm{PAH})$ in the atmospheric environment of an urban area," Environmental Pollution, vol. 183, pp. 166-174, 2013.

[26] H. Guo, S. C. Lee, K. F. Ho, X. M. Wang, and S. C. Zou, "Particle-associated polycyclic aromatic hydrocarbons in urban air of Hong Kong," Atmospheric Environment, vol. 37, pp. 5307-5317, 2003.

[27] M. Masiol, A. Hofer, S. Squizzato, R. Piazza, G. Rampazzo, and B. Pavoni, "Carcinogenic and mutagenic risk associated to airborne particle-phase polycyclic aromatic hydrocarbons: A source apportionment," Atmospheric Environment, vol. 60, pp. 375-382, 2012.

[28] J. B. Dallarosa, J. G. Mônego, and E. C. Teixeira, "Polycyclic aromatic hydrocarbons in atmospheric particles in the metropolitan area of Porto Alegre, Brazil," Atmospheric Environment, vol. 39, pp. 1609-1625, 2005.

[29] V. Mugica, S. Hernández, M. Torres, R. García, "Seasonal variation of polycyclic aromatic hydrocarbons exposure levels in Mexico city," $J$. Air \& Waste Manage. Assoc., vol. 60, pp. 548-555, 2010

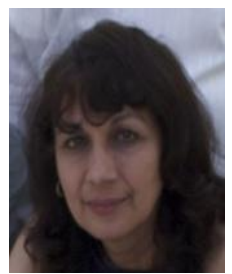

Violeta Mugica-Alvarez was born in Mexico City. She is a chemist for the Universidad Nacional Autónoma de México (UNAM). She has a master degree and a $\mathrm{PhD}$ degree in environmental engineering also from the UNAM.

She is a full time professor at the Universidad Autónoma Metropolitana and is the coordinator of the master in science and environmental engineering. 
Dr. Mugica has carried out research related to air and soil pollution, and related to the control and prevention of environmental pollution and emission of greenhouse gases. She is the author of more than 40 papers published in international journals, several book chapters in the field of environmental sciences, mainly in air soil pollution. She has participated in more than one hundred national and international conferences.

Dr. Mugica has been a consultant of the Environment Ministry and of the United Nation Development Program for the assessment of the actions to prevent air pollution in Mexico City and for the assessment of adaptation actions to face climatic change. She is a member of the National System of Researchers (SNI) at level II, which is a distinction that awards for Mexican researchers.

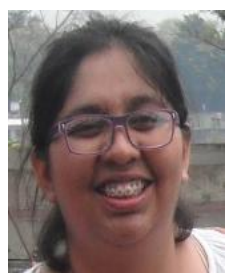

Sandra Ramos-Guízar was born in Veracruz, Mexico. She is a biologist from the University of Veracruz, México (2004). She has a master degree in environmental science and engineering from the Universidad Autónoma Metropolitana, Azcapotzalco (2014) and has worked with many issues related to sugarcane and other crops.

She has experience working in the implications of anthropogenic activities on the environment, mainly in biodiversity and sustainable management of natural resources.

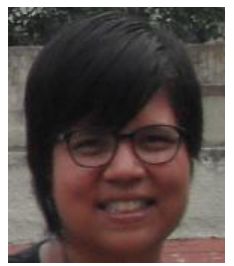

Naxieli Santiago de la Rosa was born in Chiapas, México. She is a biochemistry engineer from the Universidad Autónoma Metropolitana, Iztapalapa in 2004

She has working in pharmaceutical industries and now as a $\mathrm{PhD}$ graduate student is working in the implications of black carbon in health and climate, as well in the determination of emission factors from agriculture waste burning.

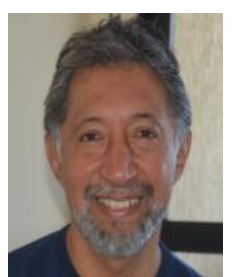

Miguel Torres-Rodríguez was born in Mexico City. $\mathrm{He}$ is a chemical engineering and received his master degree from the National Polytechnic Institute and his $\mathrm{PhD}$ in process engineering in 1993 from Claude Bernard University in Lyon France. He is a full time professor in the Universidad Autonoma Metropolitana Azcapotzalco. His research interest has been addressed in the synthesis, characterization and application of materials in environmental catalysis. He has been a visitor professor during his sabatic periods in the Institute de Recherchessur la Catalyse in Lyon France in 2006 and in the Universidad Federal do Rio Grande do Norte, Brasil in 2011. Dr. Torres is one member of (Mexican Academy of Catalysis), ACAT and one member of the Mexican Membrane society.

Dr. Torres is the author of more than 30 papers published in indexed journals related to materials applied to the environment as well as related to environmental quality. He is one member of the National System od Researchers (SNI) at level two.

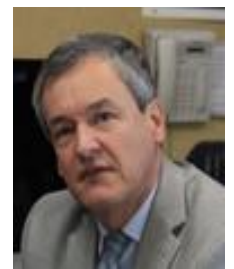

Luis Noreña-Franco was born in Mexico City. He is a chemical engineering and received his $\mathrm{PhD}$ from Manchester University in England. He is a full time professor in the Universidad Autonoma Metropolitana Azcapotzalco. His research interest has been addressed in the synthesis, characterization and application of materials in environmental catalysis. He has been a visitor professor during his sabatic periods in the University. Dr. Torres is member of (Mexican Academy of Catalysis), ACAT and member of the Mexican Membrane society.

Dr. Noreña is author of more than 20 papers published in Indexed Journals related to Materials applied to the Environment as well as related to Environmental Quality. He is a member of the National System of Researchers (SNI) at level I. 